\title{
EXCHANGE
}

\section{Takings, Exclusivity and Speech: The Legacy of PruneYard $v$ Robins}

\author{
Richard A. Epstein $\dagger$
}

The law of takings, with its ever expanding subject matter, is a sprawling affair with little intellectual coherence. Takings now include, at the very least, the following roughly-defined categories: (1) government or government-authorized physical occupation of private property ${ }^{1}(2)$ government regulation of the use or disposition of property still owned, albeit in truncated form, by private individuals; ${ }^{2}$ and (3) the imposition of price structures intended (ideally) to limit the monopoly power of public utilities while providing their owners a reasonable rate of return. ${ }^{3}$ The standards of review applied to these takings correspond to the type of case. Exacting (if not quite strict) scrutiny is required whenever the government permanently dispossesses an owner of a property interest. Rational basis review regrettably seems to be the order of the day for regulatory takings, even though this prohibition has been frayed a bit around the edges in land use cases. ${ }^{4}$ Last, some form of intermediate scrutiny is applied in rate of return cases; that is, courts allow the government substantial discretion over the mechanics of rate-setting, so long

$\dagger$ James Parker Hall Distinguished Service Professor of Law, The University of Chicago. This Article was commissioned for and presented at an American Enterprise Institute conference on legal and economic perspectives on takings held in March 1996.

' See, for example, Loretto $v$ Teleprompter Manhattan CATV Corp, 458 US 419 (1982).

${ }^{2}$ See, for example, Village of Euclid $v$ Ambler Realty Co, 272 US 365 (1926) (use); Andrus v Allard, 444 US 51, 64-68 (1979) (disposition).

${ }^{3}$ Federal Power Commission v Hope Natural Gas Co, 320 US 591, 607 (1944).

- See, for example, Lucas v South Carolina Coastal Council, 505 US 1003 (1992). 
as the regulated firm receives a "bottom line" return appropriate to its level of risk. ${ }^{5}$

Within this general framework, the least problematic cases are those in which state regulation limits the private owner's right to exclude. The normal rules of private law treat the right to exclude as an indispensable element of property, limited chiefly by a defense of necessity but subject to an obligation to compensate for any harm. Indeed, it is difficult to conceive of any property as private if the right to exclude is rejected. The property becomes, at least in part, a commons once others can enter at will, such that the owner deserves compensation, not for the total value of the property, but for the loss of its exclusive status. By stressing this element of exclusivity, I do not want to discount the importance of other elements in the bundle of property rights-most notably those of use and disposition-that today receive only limited protection under the law of takings. But I do hope to demonstrate that the attenuation of the right to exclude represents yet another unfortunate development in the modern law of takings.

In order to undertake this task, I proceed in four stages. In the first section, I contrast two approaches to the law of takings, one that treats takings disputes as derivative of or dependent on private law conceptions of property, and the second which does not. I argue that only the first maintains the integrity of constitutional doctrine, while the second, in common use today, affords insufficient protection against the expansion of state power. Second, I examine the status of the right to exclude as part of the basic bundle of property rights, chiefly in connection with Kaiser Aetna $v$ United States, ${ }^{6}$ which announced the premier status of the right to exclude. Third, I look at the range of justifications, beyond those of private necessity, that are said to limit the scope of the right to exclude, chiefly in connection with the watershed case of PruneYard Shopping Center $v$ Robins,${ }^{7}$ decided shortly after Kaiser Aetna. Finally, I look at some of the cases subsequent to PruneYard.

\section{Two ALTERNATIVE CONSTITUTIONAL APPROACHES}

The initial question is how best to approach those takings cases that threaten the right to exclude. The ideal approach does not treat disputes between individuals and the state as sui gene-

${ }^{5}$ Duquesne Light Co v Barasch, 488 US 299, 314 (1989).

6444 US 164 (1979).

3447 US 74 (1980). 
ris. Rather, it assumes that the state has the same power as any private individual, and asks whether a private party has the unqualified right to act as the state intends to act. If so, then the state can act without compensating the individual who complains of its action. Conversely, where a private individual cannot impose his will on others, the state, in order to advance the public use, can have its way only if it compensates the affected party. This tight connection between private and public disputes arises because the state functions as the designated agent for the citizens who benefit from its actions in any particular transaction. The state's right, therefore, to inflict losses on its citizens without compensation is no greater, and no less, than the right of individuals to inflict losses on each other in their private capacities.

Unfortunately, the modern constitutional approach wrenches government action out of the private context, treating government takings as sui generis without being tightly moored to any common law conceptions of property rights. Thus we are told that the baselines set by the private law do not really matter in constitutional adjudication, and that correlative concepts of property rights, such as those contained in the law of nuisance, do not play any special role in setting out the uses of and limitations on government power. ${ }^{8}$

The rejection of one standard of adjudication requires at least the implicit acceptance of a second. Once the private law is shunted aside, however, constitutional adjudication falls exclusively in the slippery arena of public law. No alternative substantive baseline is proposed; rather, the entire debate takes as its point of departure matters of administrative process (the right to participate in public debate and then to be outvoted, as it were) and adopts a stance of judicial deference to official action. Because this approach necessarily rejects any strong conception of individual rights, the deprivation of those rights fails to set off any constitutional alarms. The evisceration of the public use requirement in modern takings cases depends heavily on the deferential attitude taken toward government regulation both state and federal, ${ }^{9}$ as does the elastic set of legitimate state interests

" See, for example, Miller $v$ Schoene, 276 US 272, 279-80 (1928) (Private law of nuisance does not limit the power of the state to cut down cedar trees from which pests spread to more valuable apple trees.).

" See, for example, Hawaii Housing Authority $v$ Midkiff, 467 US 229, 240-44 (1984) (discussing and approving earlier cases that established a deferential view toward both state and federal legislative public use determinations); Ruckelshaus v Monsanto Co, 467 US 986, 1014-16 (1984) (deferring to congressional public use determination on trade secrets under the Federal Insecticide, Fungicide, and Rodenticide Act); Berman v Parker, 
that are said to justify the regulation of private property without compensation. ${ }^{10}$ The skepticism about the common law baselines for private property, moreover, is never coupled with the articulation of some alternate baseline or some explanation of how an alternate approach might function in either public or private law. Once the court declares intellectual bankruptcy on the conceptual analysis, it is only a short step to celebrate the vagaries of the political and administrative state whose procedural protections are the newly found substitute for any conception of individual rights. ${ }^{11}$

My own approach to takings starts from exactly the opposite direction. The power of government to regulate and to take is closely tied to the correlative rights and duties of ordinary individuals as regulated and determined in common law adjudication. This position does not require us to pretend that each and every common law decision is part of some seamless intellectual web. Obviously, some strong differences of opinion persist regarding the application of general common law principles to particular cases or even entire classes of problems. Constitutional adjudication thus often forces us to return to that "brooding omnipresence" of common law rules (often embodied in the Restatement of Torts, or the Restatement of Property) that is manifestly, but imperfectly, connected with the law in any given state. It is useful to give two illustrations of this process. In Ruckelshaus $v$ Monsanto $\mathrm{Co}^{12}$ an elaborate discussion of the constitutionality of certain provisions of the Federal Insecticide, Fungicide, and Rodenticide Act ("FIFRA") turned in part on whether the chemical formulas submitted for registration under the Act were private property for the purposes of the Takings Clause. The Court did not seek to fashion a brand new definition of trade

348 US 26 (1954) (reviewing federal urban renewal legislation and deferring to state and federal public use determinations).

${ }^{10}$ See, for example, Richard A. Epstein, Takings: Private Property and the Power of Eminent Domain ch 9-10 (Harvard 1985) (discussing takings and the police power); Emily Sherwin, The Geometry of Property Rights 30-33 (unpublished manuscript on file with U Chi L Rev) (discussing Supreme Court jurisprudence involving somewhat malleable standards to be applied to government regulations); Village of Euclid v Ambler Realty Co, 272 US 365, 387 (1926) (discussing "elasticity" of constitutional principles when applied to zoning ordinances).

"For a textbook illustration of the process, see Ohio Oil Co $v$ Indiana, 177 US 190, 210-11 (1900), which first notes the need to have regulation over common pool resources in oil and gas, only to hide behind a claim of legislative deference when faced with a scheme that favors one class of users (in-state drillers of natural gas) over a second class of users (out-of-state drillers of oil) when the two sets of uses are inconsistent. For criticism of the decision on this ground, see Richard A. Epstein, Modern Uses of Ancient Law 19-24 (manuscript on file with U Chi L Rev, forthcoming in 48 SC L Rev).

${ }^{12} 467$ US 986 (1984). 
secrets, but contented itself with accepting Missouri's word-forword adoption of the language of the Restatement (Second) of Torts. ${ }^{13}$ And in Lucas $v$ South Carolina Coastal Council,${ }^{14}$ Justice Scalia's inconclusive ruminations about the scope of property rights gravitated toward the definition of a common law nuisance found in the Restatement (Second) of Torts. ${ }^{15}$ These illustrations serve as useful reminders that the rationalization of common law principles in practice turns out to be somewhat tidier than the actual law of any (let alone every) jurisdiction. The effort to avoid the rights skepticism of the first alternative thus requires us to strip the common law of most of its warts and to present it in a somewhat idealized form. But lest it be thought an extravagant enterprise, it is just this view that dominates the First Amendment, where the Supreme Court resists any effort by legislatures to define certain conduct as a public nuisance before issuing an injunction. ${ }^{16}$ Rather, in area after area, only a strong conception of substantive rights supports the strict, or dare one say the intermediate, scrutiny of government action.

What then allows courts, when defining constitutionally protected rights, to diverge from actual common law decisions in a particular jurisdiction? Here one can think of several answers. First, the Constitution applies to all states equally and uniformly. When the Fifth Amendment states that private property cannot be taken for public use without just compensation, one can hardly suppose that a state is able to deflect the power of this constitutional command by defining property in ways that exclude some of its essential attributes. It would be indefensible, albeit convenient, for any state to limit property rights to the right of bare possession, thereby completely depriving property owners of their rights of use or disposition. The framers did not consecrate the rights of property solely to insure that governments had suitable objects of taxation. Similarly, lesser restrictions should not escape suspicion either: suppose that $X$ is the owner of Blackacre, what should be made of a law that allows his neighbors to graze their cattle on his property as of right without his consent? The conversion of private property into a commons

${ }^{13}$ Restatement (Second) of Torts $\S 757$, comment b (1979), defining trade secrets, quoted in Ruckelshaus, 467 US at 1001-04.

14 505 US 1003 (1992).

${ }^{15}$ Id at 1025, citing Restatement (Second) of Torts $\$ \S 822$, comment g, 826-27, 828(a)(c), 830-31 (1979).

${ }^{16}$ See, for example, Lovell $v$ City of Griffin, 303 US 444, 450-52 (1938) (rejecting a statute that defined all distributions of literature without license as a "nuisance"); $E r$ znoznik $v$ City of Jacksonville, 422 US 205 (1975) (rejecting statutory definitions of public nuisance in obscenity). 
presents many difficulties that will be addressed shortly, but surely the one incorrect answer allows the state to classify the owner's property rights as conveniently redefined, instead of acknowledging that the rights have been abridged or eliminated. ${ }^{17}$

The second and broader answer addresses the ideal characterization of the state's relationship with its citizens. It is tempting to adopt the "positivist" stance that the state can never "take" property because the state creates property rights and defines the incidents of those rights in whatever way it sees fit. Yet this conception of property is quite at odds with the notion of limited government so central to our larger political tradition. Thus, one powerful strand of the American constitutional tradition treats property as created by private actions alone. The function of the state, therefore, is not to define property rights, but to stabilize and protect the rights created exclusively by private individuals in the course of their ordinary actions. That is surely the dominant tendency in Lockean thought, and while it may not be the only tradition to influence our constitutional order-civic republicanism is another-it surely is one powerful portion of our overall tradition and understanding. ${ }^{18}$

Too often, critics of this Lockean concept of private property are also critics of natural law who assume that the "natural" mode of creating private property (occupation of land, capture of animals) has no content at all. But for our purposes, the role of natural law, understood in opposition to political or civil law, seems quite clear: if the rules are in accordance with the law of nature, then the rights acquired in property are "bottom-up rights" derived from individual acts of acquisition, not "top-down" rights derived from the state's largesse. In fact, the natural law tradition itself has always gravitated not only to a rule of first possession (in land), but also to rights in common (in water)where neither set of rights is created by government decree. Once these rights are parceled out by private actions-occupy the land and gain the riparian rights-then the state can protect the rights (by actions for trespass) and regulate them (by requiring recordation of deeds). These rules do not merely yield efficient or

\footnotetext{
${ }^{17}$ See Joseph L. Sax, Takings and the Police Power, 74 Yale L J 36, 61 (1964), which seeks to define property as "the value which each owner has left after the inconsistencies between the two competing owners have been resolved." The difficulty with this circular definition is that it justifies whatever decision is made, but does nothing to prescribe which decision should be made. Moreover, it utterly eliminates property as a barrier to further state action. For criticism of the Sax approach, see generally Sherwin, The Geometry of Property Rights (cited in note 10).

${ }^{18}$ See John Locke, The Second Treatise of Government III 25-35, in Peter Laslett, ed, Two Treatises of Government 265, 285-92 (Cambridge student ed 1988).
} 
sensible rights over property (although they do a far better job on that score than is often supposed). These rules also serve a political function. Acquisition by first possession and by grant are mutually exclusive. Property acquired by first possession cannot be acquired by government grant. The difference is not trivial. The use of property acquired by first possession may be limited, but only in ways that respect the rough equality of entitlement as between neighbors. It is no longer possible to say that state power derived from some implied reservation in the original grant which confers on the state some perpetual power of revision. No, the state is put in its place, and it is given power over property only to protect it, not to destroy it in the name of redefinition or regulation.

This natural scheme of property rights serves double duty. In addition to explaining the limitations on state power, it also gives some content to the rights between citizens. This basic approach must satisfy two constraints. First, the rights must create some parity between the individuals who hold them. When the Lockean tradition says that all individuals are free, equal, and independent in the state of nature, it gives equal weight to all three elements. ${ }^{19}$ As a first approximation, neighbors were free to do what they wanted to do with their own property; they had equal rights; and they had separate rights so that each could act independently of the other. (The word "private" traces its etymological roots to the Latin, privus, or sole.) It would not do, therefore, to have a state of nature where A could exclude B from his holdings while $B$ could not exclude A from hers.

This initial condition of parity between neighbors is consistent with several different assignments of rights. Thus each party could pollute the other's land at will; neither could do so; or both could pollute up to some low level set by the "live and let live" rule. ${ }^{20}$ The ranking of these rules cannot be made by an appeal to a principle of parity, but depends on selecting the rule that maximizes the value to each party in the relationship. The system therefore maximizes the sum of (1) the value of personal uses and (2) the value of protection that each person enjoys from use by another. Any rule that allows pollution at will, or entry into a neighbor's land to destroy crops with impunity, is an obvi-

"Id at 269-71, III 4-6.

"See Bamford v Turnley, 122 Eng Rep 27, 32-33 (Ex 1862) (Baron Bramwell) ("[R]eciprocal nuisances are of a comparatively trifling character. The convenience of such a rule may be indicated by calling it a rule of give and take, live and let live."). For my analysis of this principle, see Richard A. Epstein, For a Bramwell Revival, 38 Am J Legal Hist 246, 276-78 (1994). 
ous loser. The asserted parity of this rule only assures mutual destruction. It hardly leads to an optimal selection of rights for either party.

Conversely, the rule that allows no entry and no pollution surely does a lot better than the first possibility, but it too is capable of a universal improvement if some low level nuisances (whose use value is high and whose inconvenience to others is low) were allowed. So much of the law of nuisance is best understood as making a series of ever better approximations to an overall objective: maximize the joint value of all properties subject to law, subject to the side constraint of equality of rights between neighbors. ${ }^{21}$ In each case, deviation from the strict boundary conditions is designed to improve the overall position of the parties without regard to the direction of the new deviation. Thus, while the "live and let live" rule allows reciprocal invasions, the rules requiring lateral support impose mutual restrictions against noninvasive conduct. In both cases the general sense is that the benefits of the invasions tolerated, or the restrictions imposed, are greater than their respective costs. Strictly speaking, each of these deviations from the sharp boundary conditions improves the lot of all neighbors and satisfies a very high standard of social welfare: everyone is left better off under the new legal standard than they were under the old. Certainly no dispassionate observer of the present environmental scheme could argue that the statutory replacements (for example, Superfund, critical dune ordinances, zoning and the like) do a better job at balancing the relevant concerns between neighbors than do the common law rules they displace. ${ }^{22}$ The theme of equal treatment that resonates so strongly in the definition of individual property rights thus carries over to the question of their comprehensive modification by judicial rule. Nondiscrimination in treatment is therefore a vital protection against government abuse.

\footnotetext{
${ }^{21}$ I think that there is a strong argument that the equitable side constraint of equality (which no one should find obnoxious) is in fact a derived quantity from the first constraint of maximized value. Without the parity constraint, someone has to decide who gains the advantages, their size, and their duration. And at this point the discretion given to government is intolerable. Introduce any public choice constraint into the exercise and it becomes clear that allowing deviations from equality invites the usual rounds of rentseeking that will diminish the net value of any solution.

${ }_{22}$ See, for example, Lucas, 505 US 1003 (refusing to uphold a coastal ordinance that banned construction near the beachfront).
} 


\section{THE RIGHT TO EXCLUDE}

With this conceptual framework in place, it is now possible to return to the original question: how best to treat government regulation of the right to exclude? To start with a simple case, consider Kaiser Aetna $v$ United States. ${ }^{23}$ At its own expense, Kaiser Aetna transformed Kuapa Pond, a private body of water in the company's possession, into a navigable marina that it used and maintained for its own members. ${ }^{24}$ When Kaiser Aetna broke down the barrier that had separated its marina from the navigable waters of the United States, the federal government claimed that Kuapa Pond became part of the navigable waters of the United States, and, as such, the public was free to use the marina without interference or charge by the company. ${ }^{25}$ Waters that were once private and exclusive became public waters by federal decree. Assuming that the government was prepared to pay the freight, Kaiser Aetna, as lessee of Kuapa Pond, could do nothing to prevent its actions. But the question here was whether the United States would have to pay compensation once the waters in question were converted from private waters into a common. The government resisted this conclusion by insisting that the navigation servitude swept all aside, such that no property rights were infringed, and hence no compensation was owed. ${ }^{26}$

The key to making that argument goes back to Gibbons $v$ Ogden ${ }^{27}$ the first of the great Commerce Clause cases that held (correctly) that commerce among the several states included navigation, which was thus within the power of Congress to regulate. The leap from the power to regulate to the "navigation servitude," although far more controversial than the issue of congressional power faced in Gibbons, was made with stunning rapidity and little reflection. ${ }^{28}$ No court has said that the power to

${ }^{23} 444$ US 164 (1979).

"2 Id at 167.

$\approx$ Id at 168.

is Id at 170.

"2 22 US (9 Wheat) 1, 89-93 (1824).

${ }^{2}$ See, for example, United States v Twin City Power Co, 350 US 222, 224-25 (1956), where the Court wrote:

The interest of the United States in the flow of a navigable stream originates in the Commerce Clause. That Clause speaks in terms of power, not of property. But the power is a dominant one which can be asserted to the exclusion of any competing or conflicting one. The power is a privilege which we have called "a dominant servitude" or "a superior navigation easement." (citations omitted).

For earlier cases, see Scranton $v$ Wheeler, 179 US 141, 163 (1900) ("[T] he rights of the riparian owner are subject to the public easement or servitude of navigation."); United 
regulate land use, for example, necessarily creates a paramount interest in land that sweeps aside all private claims. Yet exactly that position became the received legal wisdom over water, which involves the familiar spectacle of the Court running from an oversight of the federal government, even during the misnamed Lochner era. Why not require the government to respect the ordinary rights of access to a body of water that are everywhere regarded as incident to the riparian lands? The navigation servitude may be sufficient to prevent individuals from taking steps to block the flow of a river (for example, letting runoff silt up navigable passages), but it hardly justifies converting private rights into public ones. The original set of circumstances, however, did not involve bodies of water that were once private and which were held public only after their owners sought access to public waterways. Yet the Supreme Court in Kaiser Aetna did not revisit its earlier decisions but contented itself instead with the protection of the right to exclude: "In this case, we hold that the 'right to exclude,' so universally held to be a fundamental element of the property right, falls within this category of interests that the Government cannot take without compensation." ${ }^{29}$ Private property did not lose its essential attribute of exclusion even though it was linked up with a navigable body of water. Access to land and access to water were governed by the same principles.

The difficulties confronting Justice Rehnquist in Kaiser Aetna stemmed from his evident need to distinguish the early cases that had accorded paramount status to the navigation easement. To do so, he made the sort of unprincipled concessions to state power that reveal the lack of intellectual coherence in his position. Thus he writes:

With respect to the [Kaiser Aetna] Marina, for example, there is no doubt that Congress may prescribe the rules of the road, define the conditions under which running lights shall be displayed, require the removal of obstructions to navigation, and exercise its authority for such other reason as may seem to it in the interest of furthering navigation or commerce. $^{30}$

States $v$ Chandler-Dunbar Water Power Co, 229 US 53, 70 (1913) (" $[E]$ very such structure in the water of a navigable river is subordinate to the right of navigation, and ... must be removed if Congress . . . shall determine that their continuance is detrimental to the public interest.").

$\approx 444$ US at $179-80$.

${ }^{30}$ Id at 174. 
But it cannot compel the use of this same Marina by outsiders without compensation.

Pour quoi? To see the difficulty with his fragile accommodation, turn to the question of the federal government's power to regulate a private road erected on private property connected to the Interstate Highway system. Why does it fall to the government, and not the private land owner, to indicate the terms and conditions under which other persons should be let onto his property? If the owner wants lower speed limits than the government thinks necessary, should the government's will prevail over the owner's when it is not prepared to pay compensation (or to shoulder the costs of any additional liability insurance attributable to its conditions)? Once an owner has the right to exclude, then the ability to set the terms and conditions of admission should lead to the optimal use of the resource for all the parties involved-as yet another of the seemingly countless applications of the Coase theorem. If visitors are asked to take the risk of submerged obstructions in private waters, then why should the government contradict? The irresistible impulse to prop up the government's plenary policies while denying them the particular object at hand should be, in a word, resisted.

The question of private access to public waters also runs smack into the recurrent prohibition of unconstitutional conditions. ${ }^{31}$ Suppose the government were to couch its regulations in the form of a bargain, by saying, "you may have access to public waters from your marina, but only if you allow members of the public to use it free of charge." That bargain, if lawful, could easily produce the outcome coveted by the United States, for it is doubtful that Kaiser Aetna's clients would value their exclusive rights to use the marina if they were denied access to public waters. If so, then the inconvenience of having public craft on private waters could easily be less than the increased rentals that could be obtained by assuring access from the marina to those public waters. The standard view of the subject is that all persons have rights of access to public roads and waters as an inherent part of fee simple ownership. The loss of that right is a taking that warrants compensation, and it will hardly do for the government to sell back to private owners the same rights that were part of their original ownership bundle.

But why are rights of access part of the original bundle? The explanation lies in the constant need to define ownership rights

${ }^{31}$ On which, for my general views, see Richard A. Epstein, Bargaining with the State (Princeton 1993). 
to minimize the bargaining breakdowns that result from erecting monopoly blockades. Here the common law recognition of a right of access to public property constrains the monopoly power of government. The state's loss of the right to exclude counts for little since public highways and public waters are open to everyone in the first place. Attaching a condition to the traditional right therefore reduces the overall value of the public and private holdings in and near navigable waters, which is why the early common law rules developed as they did. So a resort to the bargain should not be allowed to save the particular statute in Kaiser Aetna. If the government wants to secure public access to the private marina, it has to pay for it. Yet once the right to exclude was preserved, the government's appetite for control disappeared. Any individual who wanted access to the marina could negotiate directly with its owner whose services are supplied in competition with others. The basic norm that the government can stabilize, but not destroy, the institutions of common and private ownership is the only sound basis for defending the outcome in Kaiser Aetna.

\section{OVERRIDING EXCLUSION}

\section{A. The Prima Facie Wrong}

In the watershed case of PruneYard Shopping Center $v$ Robins,${ }^{32}$ the Court faced the power of the exclusivity principle, relative to the creation of the commons, in more graphic form. The factual background of the dispute was simple enough: did the owner of a shopping center have the right to exclude a political group (in this case high school students protesting UN resolutions condemning "Zionism") from distributing leaflets and soliciting petition signatures on the premises of his shopping center? The obvious point of departure for this case is Kaiser Aetna with its language on the fundamental importance of the right to exclude. If Kaiser Aetna represents the law of land as well as the law of water, then the unauthorized entry by the private parties constitutes a prima facie violation of the right of property.

${ }^{32} 447$ US 74 (1980). For the record, I should state that I worked on an unsuccessful petition for certiorari in New Jersey Coalition Against War in the Middle East $v$ J.M.B. Real Estate Corp, 138 NJ 326, 650 A2d 757 (1994), cert denied, Short Hills Associates $v$ Coalition Against War in the Middle East, 116 S Ct 62 (1995). My opposition to PruneYard long antedates that activity. See Richard A. Epstein, Takings: Private Property and the Power of Eminent Domain 64-66 (Harvard 1985). 


\section{B. Public Use}

It is here, however that the complications begin. As a matter of logic, there are two possible ways to view the right to exclude. In its stronger sense, the right is absolute: no private party can overcome it unless he procures the consent of the owner. This strong statement of principle has been dubbed a "property right" in the now standard terminology of Calabresi and Melamed. ${ }^{33} \mathrm{Al}-$ ternatively, the right to exclude could be regarded as defeasible upon payment of just compensation. To continue with the terminology of Calabresi and Melamed, the right to exclude is then protected only by a liability rule, such that the owner of the right can be forced to surrender it to an outsider upon payment of compensation.

As a private law matter, ownership is routinely protected by a strong "property rule" prohibiting purposive dispossession; a taking is therefore a "liability rule" carve-out for cases of private necessity-that is, cases where the entrant acts in imminent peril of life or limb. Indeed, it is difficult to conceive of any functioning society where individuals could occupy the house of a stranger on the willingness to pay a cash assessment, as determined by a court some years after the fact. After all, the proposition asserted is perfectly general, so the second possessor is also only protected by a liability rule. Matters are quickly subject to endless complications if the first entrant is dispossessed before he squares his accounts with the original owner. Just thinking how a liability regime works itself out with an endless array of allowable dispossessions is enough to show its instability and inefficiency in private disputes.

But the dislocation from sequential dispossessions upon payment of just compensation does not rise to the same level where the government takes property under its eminent domain power. The sequence goes exactly one round because thereafter no private party can wrest the property unilaterally from the government. Indeed the prohibition against the state loss of lands to private parties covers not only loss by condemnation, but also loss by adverse possession. The universal common law rule has long provided nullum tempus occurrit regi-no time runs against the king. ${ }^{34}$ So protecting property against state dispossession solely by means of a liability rule is certainly conceivable.

\footnotetext{
${ }^{33}$ See generally Guido Calabresi and A. Douglas Melamed, Property Rules, Liability Rules and Inalienability: One View of the Cathedral, 85 Harv L Rev 1089 (1972).

${ }^{3}$ See A. James Casner, ed, 3 American Law of Property: A Treatise on the Law of Property in the United States $\$ 15.13$ (Little, Brown 1952).
} 
The state action may be wise or foolish, but it has at least one advantage. It does not cycle endlessly.

The constitutional scheme for the taking of property does not, however, endorse the view that the government may take so long as it is prepared to pay. Rather, the Takings Clause contains unmistakable elements of both property and liability rules. The state cannot condemn property unless it is for a public use (the property rule) and when the taking is for public use, the state must still pay just compensation (the liability rule). In dealing with PruneYard, the first question is whether an entry into private property for partisan political purposes should ever count as an entry for public use, sufficient to justify a breach of the wall of ownership. The classical definition of a use tracks the meaning of public good as one that works a benefit to all members of the group; yet here neither the owners nor the shoppers receives a benefit. ${ }^{35}$ So far as the ordinary law of trespass is concerned, the owners of the property are well within their right to exclude the entrants, even if the entrants are prepared to pay just compensation for use of the space. Indeed, after PruneYard most cases have held just that. ${ }^{36}$ The discontinuity between the public and private conceptions of property rights is all too evident here.

The public use requirement is uneasy in yet another respect. The public use filter is concerned only with the use of the property in question. Nothing turns on the nature of the property used or occupied for public purposes. The protesters may prefer to enter the common areas of public shopping centers because of the easy access to large numbers of citizens and voters. But just suppose the protesters wished to extend their campaign into small stores, restaurants, or movie theaters. The Court would be hard pressed to say constitutionally that the want of a public use at long last allows the owner to bar the door. Speech in public fora is protected on small roads as well as large highways. So long as private property may be pressed into public service, differences in its size, location or use seem irrelevant to the threshold question of public use, however relevant they might be to the question of just compensation. The exact limits of this logic have yet to be tested, for the state courts that have allowed protesters into malls have limited their right of entry to the common areas, where they are subject to reasonable time, place and manner re-

${ }^{3 s}$ The classic account of the public goods problem is Mancur Olson, The Logic of Collective Action: Public Goods and the Theory of Groups (Harvard 1965).

${ }^{35}$ See New Jersey Coalition, 650 A2d at 769 (collecting cases holding that there is no general constitutional right-state or federal-to free speech in privately-owned shopping centers). 
strictions. ${ }^{37}$ So if the protesters should ever seek to expand their theater of operations, one wonders whether some clever six-part balancing test could stiffen the spine of the public use test. Could candidates for public office commandeer private office space for campaign headquarters, given the public importance of the issues they debate? One hopes not, but finding the right form of words to bar their entry will be tricky unless and until the Supreme Court backs off its ill-considered view that any "conceivable" public purpose satisfies the public use requirement. ${ }^{38}$

For the moment then, my uneasiness about allowing the protests on private property at all is just that-academic uneasiness. Today in real litigation, the elastic nature of the public use requirement dooms any effort to derail the protesters' case in PruneYard. Today republican thought and the high value that it places on all forms of participation in public debate is a strong influence in American constitutional jurisprudence. ${ }^{39}$ So for the moment at least, the entry on private lands found in PruneYard is classified, not as partisan speech, but as the quintessential public activity. PruneYard's clear logic grants all political groups equal access to shopping centers, and thus rules out any selective preference for the original protesters. So the bottom line is that, so long as state law will oblige, shopping centers can be converted into a limited public forum open to political speech of all shades and opinions. There are no traces of viewpoint discrimination that could make the particular use count as "private," or suspect under applicable First Amendment doctrine. ${ }^{40}$

\section{Substantive Defenses}

Although the public use requirement of the Takings Clause can be successfully finessed, the same cannot be said of the just

${ }^{3}$ See, for example, id at 782-83.

${ }^{34}$ See Hawaii Housing Authority v Midkiff, 467 US 229, 241 (1984) ("[W]here the exercise of the eminent domain power is rationally related to a conceivable public purpose, the Court has never held a compensated taking to be proscribed by the Public Use Clause."). The case, however, does not explicitly address the speech issue.

${ }^{29}$ For the classic statement of this position, see Frank I. Michelman, Political Markets and Community Self-Determination: Competing Judicial Models of Local Government Legitimacy, 53 Ind L J 145, 150 (1977-78) (discussing public choice and public interest models of local government legitimacy, and claiming that the attainment of individual freedom depends on community values being jointly recognized and "determinable through reasoned interchange among [members of a group]").

${ }^{*}$ The most important recent Supreme Court foray into this issue is in R.A.V. $v$ City of St. Paul, 505 US 377 (1992). For the general distinction between content-based and content-neutral restrictions, see Geoffrey Stone, Content-Neutral Restrictions, 54 U Chi L Rev 46 (1987). 
compensation issue. PruneYard strips away the exclusive right of use and converts a private shopping center into a limited commons. In light of Kaiser Aetna, that conversion of property from wholly private to partially public is, prima facie, a compensable taking. Can any new considerations be introduced in this context to block that same conclusion? This question raises a large number of hidden complications because the wall of exclusion is subject to multiple attacks that go beyond the private necessity cases. In principle, the wall could be breached with the consent of the owner, in which case the right to exclude has been waived, not overcome. Or the restriction could be overcome if the exclusion is a source of some wrong to others, which might be included in the class of nuisances (here more public than private). Third, it could be argued that even if compensation is required, it is nonetheless supplied because the rule affords advantages to all private owners of shopping centers that they could not voluntarily achieve among themselves. Or, one might argue that the mall owners suffered no damages. And last, it could be argued that the uncompensated breach of the right to exclude is warranted in this case because it satisfies the requirements of a robust protection of freedom of speech, if not under the First Amendment, then under the analogous state provisions devoted to that same end. In fact, each of these propositions has been raised in defense of PruneYard. The remainder of my argument is to show that each is as wrong as it is ingenious.

\section{Consent.}

As a matter of private law, the property owner's consent to entry and use should count as a complete defense to the taking or use of property. The institution of ownership gives people the right to exclude, not because they will invariably exercise it, but so that they can select those individuals to whom they will extend permission to enter their property. The right to exclude is good against the world, and permission then isolates those individuals who are entitled to use the property subject to whatever terms and conditions the owner chooses to impose. In the ordinary law of business invitees and social guests, consent makes entry lawful even if it does not confer any property interest on the entrants that allows them to stay after the owner has revoked the permission to enter. ${ }^{41}$ Furthermore, in the law of leases, the owner can give the entrant exclusive possession of all or part of the premises for the period of time covered by the

${ }^{4}$ See generally Restatement (Second) of Torts $\$ \S 332$ et seq (1965). 
agreement. A combination of leases and licenses permits the effective deployment and use of property. It is quite inconceivable that any system of private rights would be regarded as complete or satisfactory if the owner's exclusivity hardened into a duty as well as a right.

It is, therefore, no surprise that Justice Rehnquist sought to invoke the role of consent in order to distinguish this case from his earlier decision in Kaiser Aetna:

Most important, the shopping center by choice of its owner is not limited to the personal use of appellants. It is instead a business establishment that is open to the public to come and go as they please. The views expressed by members of the public in passing out pamphlets or seeking signatures for a petition thus will not likely be identified with those of the owner. ${ }^{42}$

Justice Rehnquist thus creates an opposition between property that is reserved for personal use and property that is open to the public generally. His implicit assumption is that these two extremes exhaust the universe of logical possibilities. Since we are not dealing with a case of personal use, then the owner has given consent to all those who wish to use the property, at least for public purposes.

His argument is plausible only because of its manipulation of the general principles of consent. Consent is the embodiment of personal choice, and it allows individuals to select the persons whom they admit and the purposes for which they are admitted. It may well be that, as a background condition, entry to the shopping center is open to all, but once certain persons are explicitly told they are not welcome, then the consent is withdrawn as to them and their entry from that time forward is a garden variety common law trespass. ${ }^{43}$

In the shopping center cases, the removal of consent from the individual users takes place in two ways. First, there is a general posting of the purposes for which entry is allowed, and if these notices are read by the entrants before entry, then their

${ }^{42}$ PruneYard, 447 US at 87 (1980). The particular passage is uttered in connection with the First Amendment issues in the case, which I discuss in Section III.C.5. But the view is widely taken. See, for example, Loretto $v$ Teleprompter Manhattan CATV Corp, 458 US 419, 434 (1982), which noted that the Court in PruneYard "upheld a state constitutional requirement that shopping center owners permit individuals to exercise free speech and petition rights on their property, to which they had already invited the general public."

${ }^{43}$ See, for example, The Six Carpenters' Case, 77 Eng Rep 695, 696 (KB 1610) (holding that abuse or violation of general consent to public entry is a trespass). 
initial entry is a trespass. Second, a specific request to leave made after entry displaces any inference that is drawn from the default position that all are welcome to enter the "public" spaces of the shopping center. That exceptions from this default position do take place is evident from the recent public stir that has accompanied the new policy in the Bloomington, Minnesota Mall, one of the nation's largest, not to allow children under sixteen in the mall at night unless they are accompanied by an adult. ${ }^{44}$ Clearly steps like this are not lightly taken, but the rationale for this particular maneuver is not unrelated to the issue of whether political protesters may use mall property as of right. Clearly invitations are qualified in order to satisfy both the needs of customers and to maximize the net returns to the mall's owners, ends that are congruent in the case at hand.

Once the mall owners state their position, Justice Rehnquist's most important point is thus a flat analytical error: these business establishments are not "open to the public to come and go as they please."45 Unlike public streets and parks, where no individuals enjoy a right to exclude, shopping malls are opened-by owners-only to some members for some purposes. No hypothetical "essence" of shopping centers prevents the invocation of consent on a selective basis and thus Rehnquist's argument is not plausible. We should be less concerned with Aristotelian categories than with the actual manifestation of individual consent or the withdrawal of such consent. It is not possible therefore to save the result in PruneYard by an appeal to any.coherent account of consent when what is offered is little more than the imposition of a nondiscrimination principle on private owners: if you are willing to admit shoppers, then you cannot discriminate against protesters. Consent is not a tied good, to be exercised on an all-or-nothing basis. Consent is divisible, and can be conditioned in an incalculable number of ways. It can be exercised by broad brush or by fine strokes. That choice lies with the owner, not with the state. The mere fact that the shopping center resisted one party's claim for entry is evidence of the falsity of that conclusion.

The divisible nature of consent, if accepted, narrows the scope of the consent defense in many other settings as well. The sit-in strikes of the 1960s were designed to open restaurants and similar establishments to blacks when owners wished to exclude

4 Robyn Meredith, Big Mall's Curfew Raises Questions of Rights and Bias, NY Times A1, A1 (Sept 4, 1996).

4s PruneYard, 447 US at 87. 
them as a matter of right. When these entries were held not to be trespasses, the suggestion was often made that the owner had consented to the entrance by opening up the premises to the public at large and could not therefore exclude black patrons. Thus, when Justices Douglas and Goldberg argued against the application of the Maryland trespass laws in the sit-in cases by speaking about "extending an invitation to the public," ${ }^{\text {"46 }}$ or by pointing out that restaurants "daily open their doors to millions of Americans, ${ }^{247}$ they engaged in the same dubious reasoning that Justice Rehnquist employed in PruneYard. There are clear justifications for some use of the antidiscrimination norm for public accommodations - of which legal monopoly is the most notable ${ }^{48}$-but consent, either express or implied-in-fact, is not one of them. Those who are explicitly and unambiguously asked to stay off the property have not been invited to enter it at the pleasure of the owner. The purported consent of the owner cannot defeat the just compensation obligation of the state, even if the public use barrier is successfully overrun.

Similarly, the logic of consent was improperly applied in the recent case of Yee $v$ City of Escondido, California, ${ }^{49}$ where Justice O'Connor took the position that since the land owners initially had invited the mobile home owners onto their premises for a limited period of time, they could not protest when state legislation barred eviction of the mobile home tenants (save for nonpayment of the rent) at the end of the lease: "Put bluntly, no government has required any physical invasion of petitioners' property." ${ }^{20}$ Put equally bluntly, only government intervention prevents the owner from removing the entrant at the expiration of the lease. But once again the question is not only whether there was consent as such, but whether there was consent to the act performed. If I allow my neighbor to enter my backyard, she does not have my consent to enter my living room or to take my silverware. When I consent to her presence in the yard for a day, she does not thereby receive consent to remain there for a week. The temporal dimension in the consent equation is as strong as the spatial, and the principle of divisibility applies to time with the same vigor that it applies to space. Consent cannot be forced into an all-or-nothing, today-is-forever mold by government

* Bell v Maryland, 378 US 226, 253 (1964) (Douglas concurring).

17 Id at 312 (Goldberg concurring).

* For the classic statement of this view, see Bruce Wyman, The Law of the Public Callings as a Solution to the Trust Problem, 17 Harv L Rev 156 (1904).

4. 503 US 519 (1992).

$\approx$ Id at 528. 
command. Rather, as a private law notion, the owner has continuous and separate choices over when consent can be offered. He may define the scope of consent by space, by time, or by condition, to as fine a grain as fits his interest. Imposing the all-ornothing constraint is a form of regulation that carries with it the unhappy consequence of blocking useful arrangements that depend on limited and conditional consent: who would let a house for a year if he could not regain possession at the end of the term? Making consent operative only in large chunks represents a manifest injustice when applied to ongoing arrangements by allowing a person to enter under one set of terms and to stay, perhaps forever, under another. All rent control statutes have the consequence of transforming holdover tenants, whom the owner could treat as trespassers at common law, ${ }^{51}$ into perpetual lessees. It was judicial ingenuity worthy of Justice Holmes ${ }^{52}$ that started the case law down the wrong path on which it continues today. ${ }^{53}$

\section{Public Nuisance.}

A second approach to the problem stated in PruneYard has been proposed by Frank Michelman in his provocative comments to the conference version of this article and renewed with characteristic vigor here. ${ }^{54}$ The central point of Michelman's comments was that, while the consent line of defense failed in PruneYard, a second line of defense held. In his view, the case could be reconciled with my general approach to takings law. The police power is not an empty conception under any view of the Takings Clause, even if the text does not explicitly embrace it. So how should that police power be defined? My own view links it to the prevention of tortious conduct by other persons, which in the land use context quickly ties the scope of the police power to the common law of nuisance. But that connection to nuisance law is

\footnotetext{
${ }^{51}$ Crechale \& Polles, Inc $v$ Smith, 295 S2d 275, 277-78 (Miss 1974) (confirming that a holdover tenant is a trespasser if the landlord does not consent to a new lease).

${ }^{52}$ Block $v$ Hirsh, 256 US 135, 157-58 (1921) (upholding a temporary rent control statute that prohibited landlords from ousting tenants at the end of a lease).

${ }^{53}$ See, for example, Cromwell Associates $v$ Mayor and Council Of the City of Newark, 211 NJ Super 462, 469, 511 A2d 1273, 1276 (1985) (sets out the current position authorizing the landlord to charge cost-justified increases in rent, assuming that the market will bear them, but does not even consider allowing him rental increases to reflect a shift in the demand for rental housing). In effect the landlord bears the risk of depreciation while the tenant gains the benefit of the appreciation in the unit, a "heads-I-win, tails-you-lose" proposition.

${ }^{54}$ See Frank Michelman, The Common Law Baseline and Restitution for the Lost Commons: A Reply to Professor Epstein, 64 U Chi L Rev 57 (1997).
} 
subject to one central difficulty of constitutional interpretation. Does constitutional interpretation depend on standard conceptions of key concepts distilled from multiple common law jurisdictions? Or must it try to make peace with the small variations in doctrine that inevitably crop up as different courts elaborate and refine any critical legal concept. ${ }^{55}$ I confess that I do not think that this problem is as large as it is sometimes made out to be if only because the level of agreement across states is far greater than is sometimes supposed, in part because of the unifying forces created by the Restatements and the standard treatises on the subject. The legal concepts in question are not so malleable as is often supposed.

Professor Michelman takes a different view and regards the variation and plasticity of common law as defeating any static conception that one might take of the overall subject. ${ }^{56}$ In his view, once I open up the Takings Clause to a public nuisance exception, say for the quite sensible reason that the ownership of property does not allow individuals to discharge wastes into public waters or throw their filth onto public lands, then I have to deal with the following situation, which is best recounted in his own words:

Lawmakers may conclude with good reason that processes of suburban and exurban development have been a direct contributing cause of the socially costly degradation suffered by urban-center spaces. Furthermore, these destructive exurbanizing processes (which is not to say that the processes have not also been constructive) have been fueled by the private provision of shopping malls, which have contributed to the destruction of urban-center civic commons and their attendant social capital. Why would not this platitudinous observation give the lawmakers just cause to require the mall developers, or their successors in title, to contribute in apt fashion to replacing the social values their profit-seeking pursuits have helped to destroy? ${ }^{57}$

The gist of the proposal in a word is that opening the malls up to political activity supplies some level of compensation for the losses attendant to the creation of malls in the first place, so that a quid pro quo has been enacted. I think that this ingenious argument fails for the following reasons.

\footnotetext{
see text accompanying note 16.

${ }^{26}$ For an elaboration of this view generally, see Richard A. Epstein, The Static Con. ception of the Common Law, $9 \mathrm{~J}$ Legal Stud 253 (1980).

${ }^{57}$ Michelman, $64 \mathrm{U}$ Chi L Rev at 64 (cited in note 54) (citation omitted).
} 
First, the case does not present any close challenge to the ordinary definitions at common law, even if we allow for the kinds of variations that creep into so decentralized a system of decisionmaking. For these purposes at least, Prosser on Torts is an accurate barometer of the present state of affairs. He begins his section on public nuisance with the standard definition of Sir James Fitzjames Stephen that refers to an act or omission "which obstructs or causes inconvenience or damage to the public in the exercise of rights common to all Her Majesty's subjects." At one level, this definition could be creatively read to support the Michelman hypothesis: "the inconvenience to the public" could come in setting up an inducement for ordinary people to abandon the downtown shopping area. But a quick look at the list of wrongs that have been found under the definition of public nuisance does not include any that resemble the competitive injury that is implicit in the Michelman definition. Instead we are treated to a long list that features:

interferences with the public health, as in the case of a hogpen, the keeping of diseased animals, or a malarial pond; with the public safety, as in the case of the storage of explosives, the shooting of fireworks in the streets, harboring a vicious dog, or the practice of medicine by one not qualified; with public morals, as in the case of houses of prostitution, illegal liquor establishments, gambling houses, indecent exhibitions, bullfights, unlicensed prize fights, or public profanity; with the public peace, as by loud and disturbing noises, or an opera performance that threatens to cause a riot; with the public comfort, as in the case of bad odors, smoke, dust and vibration; with public convenience, as by obstructing a highway or a navigable stream, or creating a condition which makes travel unsafe or highly disagreeable, or the collection of an inconvenient crowd; and in addition, such unclassified offenses as eavesdropping on a jury, or being a common scold. ${ }^{59}$

It seems that within this list of apparent diversity lies an underlying unity as to the kinds of conduct that are actionable interferences. Most of these involve the threat or danger of physical force or invasion, which operate on public spaces in a

${ }^{3 s}$ W. Page Keeton, et al, Prosser \& Keeton on the Law of Torts $\$ 90$ at 643 (West 5th ed 1984 \& Supp 1988), quoting with alterations Sir James Fitzjames Stephen, General View of the Criminal Law of England 105 (MacMillan 2d ed 1890).

${ }_{59}$ Prosser on Torts $\S 90$ at 643-45 (cited in note 58) (with twenty-four footnotes most definitely omitted). 
manner similar to actions that count as private nuisances when directed against privately owned lands and water. The remainder are moral charges, which often have undesirable neighborhood effects that can lead to the commission of garden variety crimes. The definition of public nuisance, however, is not indefinitely plastic, for Prosser goes on categorically to state that "[a]t common law, a public nuisance was always a crime, and punishable as such." And he adds in a footnote that "[n]o case has been found of tort liability for a public nuisance which was not a crime." The definition of crime refers to the common conception of crimes. The definition of a public nuisance does not remotely fit the kinds of activities that go on at any mall. The large, selfcontained area reduces the negative externalities on neighbors, and the customers who enter the premises can leave if they do not like the mix of activities undertaken. Some malls are designed exclusively for shopping and thus encourage quiet decorum. Others are fun places to be for the young and carefree. It hardly matters what portion of the market any individual mall caters to, for the nature of the benefits to mall customers hardly makes its activities a public nuisance that sets the stage for providing some in-kind competition to its disappointed competitors. Indeed, it would be odd to attach this status to the shopping mall, when everything from the NBA Finals to treks in the Catskills draws people away from the city center. The paradigm shift that is captured in the cases is quite simple. Competition expands the alternatives open to all people; and the doctrine of tort law should not be read or interpreted to treat competitive industry as a harm to disappointed competitors. ${ }^{62}$

In urging this point of view, I am not tailoring the law of nuisance to fit the law of property. The freedom of speech cases have also addressed whether certain forms of conduct could be statutorily defined as a public nuisance. The cases have uniformly followed the rules for defamation, preventing the state from defining its offenses (even by common law) to make words or conduct actionable without some conceptually sound definition, which, when all the huffing and puffing is done, looks very much like the common law rules or some variation thereof. Thus in Lovell $v$ City of Griffin, an ordinance that "deemed a nuisance" the distribution of handbills and leaflets without the permission of the city manager was quickly dispatched in part because the

\footnotetext{
${ }^{60}$ Id at 645.

id at $645 \mathrm{n} 33$.

${ }^{62}$ For an expansion of this theme, see Richard A. Epstein, The Harm Principle-And How it Grew, 45 U Toronto L J 369, 389-95, 408-09 (1995).
} 
ordinance was "not limited to 'literature' that is obscene or offensive to public morals or that advocates unlawful conduct." ${ }^{36}$ The echoes of the common law definitions reverberate loudly in the constitutional decisions.

Moreover, the evolution of the PruneYard rule does not support Michelman's contention that legislation reflects the community's disdain for the mall's usurpation of the commons. The tipoff lies in Michelman's description of the "lawmakers" who decide to open up the mall to political activity by outsiders. ${ }^{64}$ In both California and New Jersey, state legislatures and city councils played no role in fashioning the rules that allowed political protests to take place on private property against the will of the owners. Instead the entire process from soup to nuts was the outgrowth of judicial decisions. It is not difficult to see why this should be the case. As a first point, it is hardly clear that the separation of uses counts as a social detriment (as Michelman's argument implicitly presupposes). Obviously, the shopping mall reflects the interests of its patrons when it imposes the restriction in question. Many people do not want to be exposed to the political controversy at all, and those who do can find lots of other outlets, from the Internet to the mass media, to participate in political activity. The municipalities that depend on the sales and real estate taxes generated by the malls may be reluctant to jeopardize these revenue streams by driving customers away from them. And, paradoxically, some political groups may be quite happy to attract smaller groups to their demonstrations, if they could gather in places where the rallies would not generate local hostility. ${ }^{65}$ So all in all, I think that the owners of these meticulously maintained and closely managed malls can escape with dignity the charge of public nuisance.

\section{Collective Action Problems.}

Lillian BeVier's comments take a very different approach ${ }^{66}$ Whereas Professor Michelman is happy to deconstruct traditional categories of property law, Professor BeVier is in general

303 US 444, 447, 451 (1938).

64 Michelman, $64 \mathrm{U}$ Chi L Rev at 64 (cited in note 54).

*s See Hague v Committee for Industrial Organization, 307 US 496, 515 (1939) (Roberts opinion) ("Wherever the title of streets and parks may rest, they have immemorially been held in trust for the use of the public and, time out of mind, have been used for purposes of assembly, communicating thoughts between citizens, and discussing public questions.”).

${ }^{66}$ Lillian R. BeVier, Give and Take: Public Use as Due Compensation in PruneYard, 64 U Chi L Rev 71 (1997). 
sympathetic to the traditional classifications, and even with substantial portions of my views on the Takings Clause. Nonetheless, she takes issue with me in this case and applies one of the traditional justifications for overriding exclusive property rights as an explanation for the result in PruneYard. Thus she notes that the standard public good arguments offer a strong justification for limiting property rights, including the core right of exclusion. ${ }^{67}$ The usual argument holds that where the benefit in question is widely shared, no individual will have the correct incentives to produce that benefit if he has to bear all of the costs of production while enjoying only some portion of the benefit. A rule, such as that applicable for special assessments for local improvements, could allow the imposition of burdens on individuals who receive net benefits from the collective undertaking. ${ }^{68}$ Thus if the road costs one thousand and each of one hundred owners benefits by fifteen, then a special assessment of ten per unit on each owner allows for the construction of a facility from which each abutting landowner gains. No voluntary contract could ever achieve that particular result.

Professor BeVier's arresting suggestion is that the owners of the various shopping centers face a collective action problem. Each of them would be quite happy to admit some protesters to its property so long as other shopping centers followed the same policy. But each shopping center owner fears that if he alone opens up to demonstrators, he will suffer a competitive disadvantage when a disproportionate number of these protesters are drawn to his mall. A state-supplied rule mandating access could avoid this problem. Formally, the proposal could be true, but factually I believe that it is false for two reasons.

First, it was clear during the New Jersey Coalition ${ }^{69}$ litigation that the shopping center owners and their trade association collectively opposed the litigation. The revealed behavior on both fronts suggests that each of the mall owners independently opposed state intervention because the loss of the power to exclude interfered with each owner's ability to manage the property effectively, wholly without regard to other malls' policies. To be sure, the selective imposition of a duty to admit could hurt some shop-

${ }^{7}$ On which see Olson, The Logic of Collective Action at 14-16 (cited in note 35).

t* On which see generally Stephen Diamond, The Death and Transfiguration of Benefit Taxation: Special Assessments in Nineteenth-Century America, $12 \mathrm{~J}$ Legal Stud 201 (1983).

${ }^{6}$ New Jersey Coalition Against War in the Middle East v J.M.B. Realty Corp, 138 NJ 326, 650 A2d 757 (1994), cert denied, Short Hills Associates $v$ New Jersey Coalition Against War in the Middle East, 116 S Ct 62 (1995). The original lawsuit featured nine shopping center defendants. 
ping malls more than others, but it hardly follows from that observation that the general rule results in an across-the-board improvement. It could equally well result in a pro rata set of losses, whose sum is greater than the loss borne by a single shopping center if it alone opened its premises to protesters.

Second, it is far from clear that the shopping center owners shared equal levels of opposition to the program. In the New Jersey Coalition litigation, Short Hills Associates, which operates upper-end shopping centers and maintains the most rigorous set of restrictions, was the only owner prepared to file a petition for certiorari $^{70}$ notwithstanding the evident difficulty of getting the Supreme Court to review the PruneYard decision after its holding had been explicitly affirmed on several occasions. ${ }^{71}$ The cost to Short Hills Mall of changing its ambiance was greater than that to other shopping centers that occupied different market niches. There is really no surprise here, for some level of variation should be expected in every population, whether of individuals or organizations. Yet that level of variation makes it quite possible that on some occasion, one or more shopping center owners might find some advantage to allowing protesters in, or at least cash payments could persuade the owners to allow that activity at prices lower than those others would charge. But a judicial rule prevents the emergence of any market mechanism to match the potential demonstrations with the site that provides the maximum benefit, net of local inconvenience.

In reading through Professor BeVier's paper, I quickly sense that she is less troubled about the outcome in PruneYard than she is about the collateral consequences of rejecting its views on exclusivity. More specifically, she is worried that if PruneYard falls, then the public accommodations provisions of Title II of the Civil Rights Act of $1964^{72}$ will fall as well. After all, that statute authorizes a removal of the right to exclude in cases where no consent is forthcoming, and where the owner of the public accommodation has not created a public nuisance. I have observed that the enforcement of Title II has been an unqualified success in practice largely because, once the rocky transition period was

\footnotetext{
${ }^{70}$ See Short Hills Associates v Coalition Against War in the Middle East, 116 S Ct 62 (1995) (denying certiorari).

${ }^{1}$ Loretto $v$ Teleprompter Manhattan CATV Corp, 458 US 419, 434 (1982); Pacific Gas \& Electric Co v Public Utility Commission, 475 US 1, 12 (1986) (plurality); Dolan v City of Tigard, 114 S Ct 2309, 2321 (1994).

${ }^{72}$ Civil Rights Act of 1964,42 USC $\$ \S 2000(a)$ et seq (1994).
} 
over, no one saw fit to oppose it. ${ }^{73}$ I see no practical reason to repeal Title II precisely because it has been largely self-enforcing.

Even so, I do think it important to indicate the appropriate scope of the nondiscrimination principle. In my view, the nondiscrimination obligation clearly attaches to all publicly owned land, regardless of the purpose for which it is used. The nondiscrimination obligation also extends to the owners of private facilities who have local monopolies in the provision of certain services, which was historically the case with the common carriers and innkeepers. ${ }^{74}$ But it is important to state the reason for this principle. It is not that these properties are simply important. It is that innkeepers and common carriers historically had a monopoly position and the obligation to take all comers at a reasonable price was the best way to curb that power. When the monopoly position is lost, as is typically the case with restaurants, the obligation to receive all comers should cease. This approach makes a huge difference in practice not because of questions of race, sex, and age, but because of the extensive new obligations imposed on owners of public accommodations, broadly defined, under the Americans With Disabilities Act ("ADA"). ${ }^{75}$ Here the nondiscrimination obligation has been transformed into one of equal access regardless of cost. Even within the traditional logic of the common carrier rules, the ADA is something of an anomaly because it does not require each customer to cover the cost of his service, as the older rules did. But it is far easier to introduce an extensive set of obligations if the barrier of exclusivity has first been overcome by the initial antidiscrimination rules on public accommodations. The upshot, two generations later, is an enormous public works program that imposes heavy private costs for, in many cases, limited public benefits. So my fear in the end is the opposite of Professor BeVier's. She is afraid that the principle of Title II will be compromised where it matters the most. My view is that if Title II were scrapped tomorrow, shopping center owners would scramble to proclaim to the world that all persons were welcome into their malls regardless of race or sex. They would certainly pause before they made the same promise with respect to age, given some difficulties in controlling teenagers at night. Nor do I think that they would be in the slightest hostile to

\footnotetext{
${ }^{73}$ See Richard A. Epstein, Forbidden Grounds: The Case Against Employment Discrimination Laws 126-29 (Harvard 1992).

"See, for example, Joseph Story, Commentaries on the Law of Bailments $\$ 476$ (Little Brown 9th ed 1878) (James Schouler, ed); Bell v Maryland, 378 US 226, 296-300 (1964) (Goldberg concurring) (gathering authorities).

"3 Americans With Disabilities Act of 1990, 42 USC $\$ 12101$ et seq (1994).
} 
persons with disabilities. The ill will from exclusion would prove very costly to them. But I do think that the kinds of accommodations that they would be prepared to make would be far less extravagant and wasteful than those now required under the law. Professor BeVier should not blink or abandon her strong instincts toward limited government when faced with the challenge of what happens to Title II.

\section{Damages.}

Thus far I have addressed the substantive arguments used to defend the decision in PruneYard. Yet another approach posits that deprivation of the right to exclusivity caused no damages. Here, as the Supreme Court has rightly reminided us, the basic position of the Takings Clause is that the owner's loss, not the gain to the state, provides the basic measure of compensation. ${ }^{76}$ But on this issue too the Court in PruneYard takes a naive view. It assumes that there were no damages to speak of because the mall's other economic activities could proceed side-by-side with the petitioners' solicitations, and the owners were free to introduce reasonable "time, place, and manner regulations that will minimize any interference with its commercial functions."

But just as the PruneYard decision misunderstands the logic of property rights, so too it misunderstands the logic of harm and compensation. Time, place, and manner regulations do not grow on trees. They have to be promulgated and defended against parties who argue that the restrictions are a mere pretext to the now forbidden rule of exclusion. Yet the costs of meeting this judicial obligation are not compensated under the applicable legal rule, but are borne by the landowner who lacks the taxing power to defray the expenses.

More importantly, this conception of value assumes that the only compensable losses are those measurable economic losses associated with the intrusion. Yet if these are as close to zero as the Court seems to suppose, then we should be hard-pressed to explain why any shopping center insists, often vehemently, on a no-solicitation-no-distribution rule. That policy is itself costly to enforce, so that private parties would only incur the relevant costs if they perceived some (subjective) benefit of an equal or greater amount. For these purposes, it is not critical that the

\footnotetext{
${ }^{76}$ See United States $v$ Miller, 317 US 369, 375 (1943) (" $[$ TT] he owner is to receive no more than indemnity for his loss, his award cannot be enhanced by any gain to the taker.").

747 US at 83.
} 
Court identify what this benefit is. But it should be willing to presume that property owners know enough about their own businesses to decide what policies are, or are not, in their own best interests.

Yet the explanation for the no-distribution policy is not difficult to find. The operation of a shopping center depends on the creation of an ambiance in its public and private spaces. The consistency in appearance and product line is generally thought to be absolutely essential to a shopping center's ability to attract and hold the right kind of paying customer base. Any doubters of this general proposition need only consult Malcolm Gladwell's New Yorker article, The Science of Shopping. ${ }^{78}$ The article presents the theories of Paco Underhill, a prominent retail consultant for whom success and failure are both found in the small details in design and location that ordinary observers, and indeed professional retailers, could easily overlook. Visual cues seem to matter for everything: windows have to be slanted at just the right angle to be accessible to viewer traffic. Displays must be angled to the right, which is the natural direction in which shoppers go in entering a store-so great is the principle of the Invariant Right. No items of value should be located in the Decompression Zone, which shoppers pass through after leaving the public space and entering the store.

The key to retailing, therefore, is total control and mastery over interior spaces. If a political solicitation prevents customers from lingering over coffee or window shopping, then the level of sales, and hence of profitability, will fall, even if no particular lost sale can be traced back to any particular political activity. These "soft" costs are critical in making business decisions: they are the stuff of the "practical knowledge" to which Hayek turns when he explains the "impossibility of central planning" and direction. ${ }^{79}$ Yet these costs are too often lost in the judicial judgments about what happens.

Accordingly, the right rule for takings cases of this sort is to take evidence on the diminution in property value as a result of the intrusion in question. Although the evidence is hard to come by, it is surely a mistake to place the burden of proof on the shopping center owner before awarding any compensation. The state which forces an involuntary loss on its citizens should not

\footnotetext{
${ }^{78}$ Malcolm Gladwell, The Science of Shopping, The New Yorker 66 (Nov 4, 1996). Gladwell's work was inspired by William Whyte's earlier studies on public spaces such as parks and plazas in order to see which worked and which did not. See William H. Whyte, The Social Life of Small Urban Spaces (Conservation Foundation 1980).

${ }^{29}$ John Gray, Hayek on Liberty 25-26, 36-40, 83 (Basil Blackwell 1984).
} 
be allowed to use difficulties in estimating the cost of the loss to evade an obligation to compensate. So the direct costs of allowing the demonstration, the potential liabilities that stem from its operations, some allocation for the space, a percentage of lost sales, and some allowance for goodwill should be awarded, even if the calculations are to some degree speculative given the soft (but real) nature of the losses. And once these elements are allowed, it is doubtful that the activity will continue, for demand falls as price rises, and that is what the just compensation principle is all about. It is doubtful that public funds would be invested in paying the compensation for a private group, and very doubtful that the group would not shift to some other form of political activity if forced to pay compensation: which is as it should be, for the price component of the Takings Clause is designed to shift the nature and intensity of both public and private activities.

\section{The First Amendment.}

The analysis of PruneYard has not yet run its course. Indeed within the traditional doctrinal framework, the case marks a profound transition from pure takings analysis to a multi-layered case because of the ostensible collision of First Amendment and Fifth Amendment values. It is an evident sign of intellectual confusion when subtle First Amendment arguments can be routinely raised on both sides of any dispute: protesters and demonstrators are obviously engaged in speech-related activities, and claim that the denial of entry derogates their First Amendment rights. ${ }^{80}$ Yet the shopping center claims that it does not wish to be tagged with the protesters' viewpoint or be required to subsidize their activities by furmishing them with space and shopping center amenities. The confusion is partially corrected by posting notices and disclaimers, but the subsidy point cannot be answered by any disclaimer: the Mall may oppose the message and still be required to dedicate its space to its advancement.

\footnotetext{
${ }^{85}$ Claims of this sort were in fact sustained in the pre-PruneYard decision of Amalgamated Food Employees Union Local 590 v Logan Valley Plaza, Inc, 391 US 308, 319 (1968) (accepting union picketing in a mall parking lot as protected by the First Amendment), but were repudiated in Lloyd Corp v Tanner, 407 US 551, 562-63, 567-68 (1972) which held that the First Amendment did not require the private owner of a shopping center to allow entrance onto the property. Logan Valley was explicitly overruled in Hudgens $v$ NLRB, 424 US 507, 518-21 (1976). The decision in Lloyd did not, however, prevent states from accepting the First Amendment arguments of the protesters, and PruneYard is most notable for its agnosticism, by rejecting First Amendment claims of both the entrants and the owners, and rejecting the owner's takings claim under the Fifth Amendment.
} 
The hard question of constitutional interpretation is whether one reads the First Amendment in opposition to the Fifth Amendment or in harmony with it. Here the latter approach seems to make far more sense, for why would anyone draft a document whose neighboring commands systematically operate at cross-purposes? In other settings, my right to speak does not entail a right to use your telephone for long distance calls at your expense. Small therefore is the perceived difference between commandeering phones and commandeering space when both are done without compensation. In response, it could be said that the protection afforded a home is not the same protection that is afforded a shopping center because, to borrow a phrase from an earlier era, the shopping center is "affected with the public interest." $" 11$

Unfortunately, this argument fundamentally misunderstands the logic of property rights. When two or more individuals combine their rights, they do not gain any additional advantage over third persons, but, by the same token, their combined efforts should not subject them to any additional obligations either. The rights and duties of both $A$ and $B$ are, so to speak, conserved against the world. This constraint, moreover, binds no matter how many times the rule is applied. What is good for A and B can be carried out with a thousand persons as well as with two. Any other rule induces strategic behavior by the original contracting parties: either they will trade in order to gain rights against third persons, or they will refrain from making trades that are otherwise beneficial for fear that they will lose rights to third persons. So long as the optimal adjustment is created (by the tort law) between strangers, the existence of some voluntary transactions ought not to scramble that which has been well done the first time. The size of the individual holdings may vary but the aggregate set of rights remains constant. The major, perhaps sole, exception to this rule is when one group exerts a dominant power over some given resource; but healthy competition, whether among shops or shopping centers, erases this threat of monopoly power. Antitrust law aside, the shopping centers should not be regarded as sacrificing their right to exclude as payment for their aggregation of separate land under common ownership.

${ }^{* 1}$ See Munn v Illinois, 94 US 113, 126 (1876), quoting Lord Chief Justice Hale, De Portibus Maris, in Francis Hargrave, ed, A Collection of Tracts Relative to the Law of England 45, 78 (E. Lynch, et al 1787). 
It need not follow, however, that the combined owner will seek to exercise its ownership rights in the same way as the separate individuals who contributed to the common property. Shopping centers do not make money by a remorseless policy of exclusion-they make it by invitation-so we should expect the terms and conditions to vary from that of shopowners as a function of the objectives of the owners in the combined scheme. But it hardly follows that they should be found to surrender the rights that they want simply because they have waived the rights that they do not wish to preserve. The general public is invited to shop because of the anticipated gains from their arrival. The political demonstrators are kept out because of the owner's anticipated business loss from their arrival. Both those actions make sense, and there is no reason in law or principle why the two decisions have to be linked under the First Amendment or anywhere else. The owners can admit one group and exclude the others. The forces of competition will make sure that the gains from all beneficial transactions are captured.

Stated otherwise, the logic of contract and exchange should not be suppressed or deflected by any claim of freedom of speech. Under the Constitution, the purpose of freedom of speech is not simply to have more speech, but to have speech that fairly reflects the sentiments of the population at large. ${ }^{82}$ Covert subsidies, such as those involved in PruneYard, are an enemy to freedom of speech every bit as much as explicit taxes or oppressive regulations. Justice Rehnquist's suggestion that the proposed rule of guaranteed access does not engage in any viewpoint discrimination ${ }^{83}$ is correct only at the formal, but not the practical level. At ground level, it seems clear that some speakers (usually those who are left-wing and antiestablishment types) will be far more likely to commandeer these resources than will other speakers. That implicit shift of resources is certainly permissible in connection with the use of public fora that have from time out of mind been open to all. But it is far more troublesome in this context. As a general matter, freedom of speech is best protected when property rights are well-defined. Whatever one thinks about the merits of PruneYard, its impact on the overall political discourse is tiny in comparison with rules that allow private individuals to own and operate their printing presses as they see

\footnotetext{
${ }^{82}$ Just that mistake is made, for example, in New York Times $v$ Sullivan, 376 US 254 (1964), which in its zeal to insulate libel defendants from suits has allowed major grievances to go unredressed. For my critique of that decision, see Richard A. Epstein, Was New York Times v Sullivan Wrong?, 53 U Chi L Rev 782 (1986).

${ }^{23}$ PruneYard, 447 US at 87-88.
} 
fit, or to conduct political meetings and rallies by invitation on private property. PruneYard weakens those institutional supports to property by allowing individual owners to force their way onto the property of others for political ends. But breach of the public use wall should not excuse the protesters, or the state, from paying compensation for pressing private property into public service. Neither public use, nor consent, nor a desire for more or better speech alters that conclusion.

\section{THE AFTERMATH OF PRUNEYARD}

The interaction between the Fifth and First Amendments evident in PruneYard has also played a role in some subsequent cases, and these too deserve brief comment. In Pacific Gas \& Electric Co $v$ Public Utilities Commission, ${ }^{84}$ the question before the Court was who owned the "excess" space inside the billing envelopes sent by Pacific Gas \& Electric ("PG\&E") to its customers. This space was created in virtue of the fact that even after the bills had been included, the envelope could hold additional material before the price of postage increased to the next level. PG\&E had used the space to distribute its own monthly newsletter, but the Commission claimed that the space belonged to the ratepayers and stipulated that certain groups that had opposed $P G \& E$ in the past had a right to use the space four months out of the year.

Here the Court struck down the requirement largely because it required PG\&E to use its property to express the viewpoints of others. In so doing, it followed the tradition of Miami Herald Publishing Co $v$ Tornillo ${ }^{85}$ that held that newspapers could not be converted into a common carrier of sorts by being forced to carry the replies of other individuals whom they had criticized. In the course of his plurality opinion in Pacific Gas \& Electric, Justice Powell distinguished PruneYard because it had not addressed the question of forced association squarely raised when the messages included inside the billing envelope were antithetical to the position of the Utility Company. ${ }^{86}$ Once again the question of the commons obliquely arose when the Commission claimed that the ratepayers owned the extra space inside the envelopes and they could therefore do with their property what they pleased. The Court observed that even if the ratepayers owned the excess space, PG\&E still owned the envelope and, therefore, could ex-

\footnotetext{
475 US 1, 11 (1986) (plurality).

*5 418 US 241, 256-57 (1974).

क 475 US at 12.
} 
clude the undesired messages in order to make sure that its own property, the envelope, was not pressed into the service of a hostile cause. ${ }^{87}$

This tactic of evasion, however, does not answer two complications. First, if the excess space in the envelope is owned by the ratepayers, then even if they cannot use it, surely they could exclude PG\&E from filling it to present its own messages: after all, why should PG\&E be able to use the ratepayers' property for its own advantage? In effect, the split ownership between envelope and excess space creates the standard holdout problem where each side can veto any use by the other, such that neither side can use the resource. Hence Justice Powell's insistence that PG\&E could carry on the traditional distribution of its newsletter is not justified. Rather each side can barricade the other.

Second, if this envelope has split ownership, could the same be said about all other envelopes that are sent by PG\&E with excess space, including those sent to suppliers, advertisers, and the like? The very purpose of the institution of property is to avoid the legal creation of a commons that inhibits the use of resources. The areas of natural commons, such as water, provide instructive examples where the efficient utilization of a resource is promoted by shared ownership. The ordinary envelope does not have the same array of rich and interlocking uses as a flowing river. Independent of regulation, it seems clear that the space inside an envelope is always owned by the envelope owner, and there is no reason why that result should change when dealing with a regulated industry. There is no need for agnosticism on this particular point. It is quite enough to take the sensible position that the state can only convert this private property into an odd sort of commons upon payment of just compensation, which, in practice, need not be calculated because the mere suggestion of a positive price will scare away potential purchasers.

The second of the forced entry cases is Turner Broadcasting System, Inc $v$ United States, ${ }^{88}$ where the cable companies challenged the "must carry" provisions of the Cable Act of $1992 .^{89}$ The basic function of these provisions is to require cable networks to carry the over-the-air signals of local broadcasters without charge. The impetus behind the rule was the fear that the increased penetration of cable could lead to the extinction of the

${ }^{87}$ Id at 13.

\& 114 S Ct 2445 (1994).

${ }^{89}$ Cable Television Consumer Protection and Competition Act of 1992 , Pub L No 102385, 106 Stat 1460, 1471-77, codified at 47 USC $\$ \S 534(\mathrm{~b})(1)(\mathrm{B}), 534(\mathrm{~h})(1)(\mathrm{A}), 535(\mathrm{a})$ (1994). 
broadcast networks, causing special harm to homes that did not purchase or could not reach cable television. Once again the case was largely fought on First Amendment grounds. In that vein, the Court first held that a standard of intermediate scrutiny applied to the restrictions, ${ }^{90}$ and then recognized that Congress had an "important and substantial federal interest" in "protecting noncable households from loss of regular television broadcasting service due to competition from cable systems." 1

The difficulties in Turner Broadcasting come from the protectionist rationale that bears a haunting resemblance to Professor Michelman's public nuisance explanation. Thus, while it seems clear that competition always places established businesses at risk, the preservation of the old technology against the incursions of the new hardly seems a ground on which to make the cable companies into common carriers open to the traffic of their business rivals. The networks have the option to shrink their staffs, reduce their independent programming, and share purchases with cable operators, in order to protect their business, and if they fail, which is doubtful, it is difficult to see a social interest in propping them up. But even if the common carrier status is imposed, why is there no compensation for the cable companies? Here the conversion of private into common property is a partial taking even if the case is suffused with First Amendment issues. At the very least, some fraction of the advertisement revenues or some standardized fee for service should be part of the mix, similar to the pooled payments that are often used in copyright cases. ${ }^{92}$ Indeed once the compensation is forthcoming, there is less of a need to assess independently the burdens that the must-carry provisions impose on the cable operators, which was yet another part of the program on remand. ${ }^{93} \mathrm{In}$ stead, the price system could cushion the blow and give the cable companies a revenue stream with which to expand their own ca-

Turner Broadcasting, $114 \mathrm{~S} \mathrm{Ct}$ at 2469. The intermediate scrutiny standard applicable to content-neutral regulations is as follows:

[A] government regulation is sufficiently justified if it is within the constitutional power of the Government; if it furthers an important or substantial governmental interest; if the governmental interest is unrelated to the suppression of free expression; and if the incidental restriction on alleged First Amendment freedoms is no greater than is essential to the furtherance of that interest.

United States v O'Brien, 391 US 367, 377 (1968).

"Turner Broadcasting, $114 \mathrm{~S}$ Ct at 2461, quoting Capital Cities Cable, Inc v Crisp, 467 US 691, 714 (1984).

$5_{2}$ Fortnightly Corp v United Artists Television, Inc, 392 US 390 (1969); Copyright Act of 1976, 17 USC $\S 111$ (1994). For discussion, see J. Thorne, P. Huber, and M. Kellogg, Federal Broadband Law \$ 10.6.2 (Little, Brown 1995).

${ }^{53}$ Turner Broadcasting, $114 \mathrm{~S}$ Ct at 2472. 
pabilities. Turner Broadcasting constitutes a serious error by asserting that the proper judicial role is to require an evaluation of consequences from all points of view rather than require a cash payment for the privilege of using someone else's resources.

\section{CONCLUSTION}

The protection of private property under the Constitution has not proceeded in an orderly or coherent way. All too often there are ad hoc compromises that do not reflect a consistent overview of how government ought to proceed. In contrast to the now-accepted ways of doing business, it seems sensible to adopt a principle that says, "the more you take the more you pay." That rule can apply when the government takes six acres of land instead of four. But it also applies when government forces the holders of private property to surrender their right to exclude. The size of the shifts in property rights should only determine the amount of compensation. Yet in PruneYard, these obvious principles were neglected. The consequences of that neglect are not random, but seem systematically to favor the expansion of government power for purposes that on balance are more mischievous than beneficial. Righting the balance in takings law is by now a familiar theme. But it is not one that has lost its urgency through repetition. 